Personalidade Acadêmica Homenageada:

Augustus B. Cochran III (Agnes Scott College)

\title{
DESOBEDIÊNCIA CIVIL: A PARALISAÇÃO DOS CAMINHONEIROS EM 2018 NO BRASIL À LUZ DA TEORIA DE HENRY DAVID THOREAU
}

\author{
CIVIL DISOBEDIENCE: A 2018 TRUCK STOPPER IN BRAZIL IN THE \\ LIGHT OF HENRY DAVID THOREAU THEORY FUNDAMENTAL OF \\ AUTOMATION PROTECTION AS A JOB PROTECTION MECHANISM
}

\section{SOIANE MONTANHEIRO DOS REIS} Mestranda em Direito Empresarial e Cidadania no UNICURITIBA, Advogada, formada pela PUC-PR; Pós-Graduada em Direito Tributario pela UNICURITBA.

\section{RESUMO}

O presente artigo tem o objetivo de fazer uma reflexão: até que ponto a sociedade está obrigada a seguir Leis sobre as quais não concorda? E ainda, em que medida a resistência pacífica a uma Lei, considerada injusta, pode persuadir o legislador a modificá-la? A motivação para pesquisar o assunto se deu pelos exemplos históricos de resistência pacífica em outros países, como por exemplo, a luta de Gandhi pela independência da Índia, a conquista dos Direitos Civis, nos Estados Unidos, liderada por Martin Luther King e pela grandiosidade do movimento chamado "greve dos caminhoneiros" que ocorreu em maio de 2018, no Brasil, que abalou a estrutura política do governo vigente, gerou agitação que resultou na suspensão de serviços e atendimentos essenciais em hospitais e postos de saúde, levou uma parcela significativa da população a dar apoio aos grevistas, (havia sinal de 
Personalidade Acadêmica Homenageada:

Augustus B. Cochran III (Agnes Scott College)

insatisfação do povo no tocante às denúncias de corrupção dos políticos). José Ribamar da Costa Assunção (2018), em seu Artigo A "desobediência civil" na greve dos caminhoneiros, considerou o movimento como nítida existência do locaute, uma vez que não resumia ao transporte do combustível para o posto, e sim ao "imposto" cobrado das distribuidoras. Enfatizando, as infrações à Lei de Greve, uma vez que feita por profissionais que exerciam atividade considerada como essencial, tudo com violação ao artigo 10, I, II, III e V, da Lei Federal 7.783, de 28 de junho de 1989, também infringiram, clara e acintosamente, os artigos 181, VII, e 182, V (este, infração gravíssima), do Código de Trânsito Brasileiro (Lei Federal 9.503, de 23/9/1997). Violaram e desrespeitaram o artigo 5ำ XV, da Constituição Federal, que contempla a chamada liberdade de locomoção das pessoas, e o inciso XVI do mesmo artigo, que diz com o direito de reuniões pacíficas. Para o desenvolvimento da pesquisa, o marco teórico é Henry David Thoreau, em sua obra: "Desobediência Civil”, onde a ideia é trazer à pesquisa o fundamento do pensamento do autor, para analisar casos antigos e contemporâneos de Desobediência Civil e sua eficácia na sociedade, e, principalmente, identificar se a "Greve dos Caminhoneiros", pode ser caracterizada, no conceito genuíno de Desobediência Civil e qual foi a sua pujança. Para a realização da pesquisa, no método dedutivo, utilizou-se material bibliográfico referente ao tema, de dados apresentados pela imprensa à época dos fatos e do entendimento acerca da natureza jurídica da greve, segundo doutrina trabalhista. A ideia central da pesquisa é exatamente refletir acerca do direito à desobediencia civil, quando a Lei é imposta apenas como forma de coibição. As críticas de Thoreau ao governo têm por base o aspecto moral de determinada ação ou política governamental, sendo o desrespeito à lei um ato e dever de consciência do indivíduo. Dessa maneira, a Desobediência Civil surgiu como instrumento de proteção pacífica contra a Lei considerada injusta. 
Personalidade Acadêmica Homenageada:

Augustus B. Cochran III (Agnes Scott College)

PALAVRAS-CHAVE: Greve Caminhoneiros; Desobediência Civil; Resistência Pacífica.

\section{REFERÊNCIAS}

ASSUNÇÃO, José Ribamar da Costa. A "desobediência civil" na greve dos caminhoneiros. Revista eletrônica Consultor Jurídico (postado em 4 de junho de 2018). Disponível em: https://www.conjur.com.br/2018-jun-04/jose-ribamardesobediencia-civil-greve-caminhoneiros . Acesso em 19 abr. 2019.

BEZERRA, Eudes Vitor. BRAGA, Sergio Pereira. SIQUEIRA, Leonardo Cortez Casol. Análise ao Direito de Resistencia sob a ótica da Ocupação em Unidades de $\begin{array}{lllllll}\text { Conservação Ambiental. } & \text { n. } 22 & \text { v } & 3, & 2017 .\end{array}$ http://revista.unicuritiba.edu.br/index.php/percurso/article/view/2645

BRASIL. Código de Transito Brasileiro, Lei no 9.503, de 23 de setembro de 1997. http://www.planalto.gov.br/ccivil 03/leis//9503.htm. Acesso em 19 abr. 2019.

Constituição da República Federativa do Brasil 1988. http://www.planalto.gov.br/ccivil 03/constituicao/constituicao.htm. Acesso em 19 abr.2019

Lei Federal no 7.783, de 28 de junho de 1989. http://www.planalto.gov.br/ccivil 03/leis/l7783.HTM. Acesso em 19 abr. 2019.

MACHADO, Marcelo Ferreira. Diferença entre Paralisação dos Motoristas de Carga e a Greve e o Lockout: Uma Análise Jurídica. Revista Eletrônica (postado 12/06/2018). Disponível em: https://emporiododireito.com.br/leitura/diferencas-entrea-paralisacao-dos-motoristas-de-carga-e-a-greve-e-o-lockout-uma-analise-juridica. www.bbc.com (Acesso: 18/04/2019). Acesso em 19 abr. 2019.

NASCIMENTO, Amauri Mascaro. Compendio de Direito Sindical, ed. 6. São Paulo: LTr, 2009

THOREAU, Henry David. A Desobediência Civil (1817-1862). Trad. e Intr.. Daniel Moreira Miranda, (2016), ed. EDIPRO, 2016. 